\title{
THE USE OF NEGATIVE BIAS POTENTIAL FOR STRUCTURAL ENGINEERING OF VACUUM-ARC NITRIDE COATINGS BASED ON HIGH-ENTROPY ALLOYS
}

\author{
O.V. Sobol' 1,*, A.A. Andreev ${ }^{2}$, V.F. Gorban' ${ }^{3}$, H.O. Postelnyk ${ }^{1}$, \\ V.A. Stolbovoy ${ }^{2}$, A.V. Zvyagolsky ${ }^{1}$, A.V. Dolomanov ${ }^{2}$, Zh.V. Kraievska ${ }^{I}$ \\ ${ }^{1}$ National Technical University “Kharkiv Polytechnic Institute”, Kharkov, Ukraine \\ "E-mail:sool@kpi.kharkov.ua; \\ ${ }^{2}$ National Science Center "Kharkov Institute of Physics and Technology”, Kharkov, Ukraine \\ E-mail:aandreev@kipt.kharkov.ua; \\ ${ }^{3}$ Frantsevich Institute for Problems of Materials Science, Kyiv, Ukraine
}

The effect of negative bias potential $\left(U_{\mathrm{b}}=-40,-110\right.$, and $\left.-200 \mathrm{~V}\right)$ during the deposition of multi-element coatings on their composition, structure and mechanical properties was studied. It was established that during the transition from a multi-element alloy to a nitride, a single-phase state possible to form on its basis (based on the fcc metal lattice, structural type $\mathrm{NaCl})$. In this case, the composition $(\mathrm{FeCoNiCuAlCrV}) \mathrm{N}$ of coatings with increasing $U_{\mathrm{b}}$ is depleted by the element with the lowest enthalpy of formation of nitride $(\mathrm{Cu})$. In (AlCrTiNbSi)N and (AlCrTiZrNbV)N coatings, the content of low-mass elements ( $\mathrm{Si}$ and $\mathrm{Al}$ ) decreases with increasing $U_{\mathrm{b}}$. In (TiZrHfVNb)N coatings of strong nitride-forming elements with increasing $U_{\mathrm{b}}$ to $200 \mathrm{~V}$, the composition practically does not change. The structure of such coatings is characterized by the presence of a texture with the [111] axis. The presence of weak nitride-forming elements in $(\mathrm{FeCoNiCuAlCrV}) \mathrm{N}$ coatings leads to the formation of texture [110] for large $U_{\mathrm{b}}=110 \ldots 200 \mathrm{~V}$. In such coatings, the hardness does not exceed $35 \mathrm{GPa}$. It is shown that to achieve high hardness at high $U_{\mathrm{b}}$ it is necessary to increase the content in the high-entropy alloy of elements with high nitrideforming ability. In this case, in (TiZrHfVNb)N coatings (made of strong nitride-forming elements with a large mass) at $U_{\mathrm{b}}=200 \mathrm{~V}$, the hardness exceeds $45 \mathrm{GPa}$.

PACS: 64.75.St, 81.07.Bc, 62.25.-g, 61.05.cp, 61.82.Rx

\section{INTRODUCTION}

The traditional approach to creating new materials is to select one element as a basic element. To obtain the desired combination of mechanical and/or other operational properties, the base material is alloyed with additional elements [1, 2]. As basic elements, $\mathrm{Fe}, \mathrm{Cu}, \mathrm{Al}, \mathrm{Ni}$, $\mathrm{Mg}$, etc. are used. However, in recent years, thanks to the use of the structural engineering method (structural design), it has been possible to develop new mechanisms for the formation of composite materials [3-5], expand the possibilities of managing the structural state in non-equilibrium conditions [6] and stabilize metastable phase-structural states [7].

Based on structural engineering, the highest mechanical properties were achieved for coatings obtained by vacuum-plasma methods [8-10]. This is determined by a significant expansion of the possibilities of controlling the structural state in non-equilibrium conditions typical of modern methods for obtaining materials from plasma flows $[11,12]$. In vacuum-plasma methods for obtaining materials, super fast thermalization of atoms occurs [13]. This limits the diffusion mobility of atoms and leads to the formation of a disordered solid solution [14]. To a large extent, high mechanical properties are achieved in multi-element coatings as a result of decomposition of supersaturated solid solutions (spinodal type) [15] and ordering [16].

In recent years, structural engineering has been actively used to produce new multicomponent (highentropy) alloys containing (as a base material) five or more elements in equal (equiatomic) proportions $[17,18]$. Such alloys form disordered solid solutions
[19]. Due to this, various mechanisms of their hardening can be used: solid-solution, dispersion, deformation, etc. [20].

Compared with traditional materials, high-entropy alloys (HEA) have significantly higher functional properties. These properties include: high temperature stability [21], high strength [22], high plasticity and fracture toughness [23, 24].

Note that high configurational entropy, caused by mixing five or more elements, contributes to the formation of a disordered solid solution. Unlike traditional alloys, HEA are formed with fairly simple crystal structures (for example, body-centered cubic (BCC), facecentered cubic (FCC) or hexagonal close-packed (HCP) $[25,26])$, and not from several intermetallic compounds with complex microstructures.

Another effect characterizing HEA is a strong lattice distortion caused by a large difference in the atoms size in a unit cell. Lattice distortion is commonly used to explain the observed hardening of a multicomponent phase compared to binary or ternary systems. To quantify the lattice distortion, the $\delta$ parameter is commonly used. It represents the average deviation of the metal radii of the elements from the average radius [27]:

$$
\delta=\sqrt{\sum_{i=1}^{n} c_{i}\left(1-\frac{r_{i}}{\bar{r}}\right)^{2}}
$$

where $c_{i}$ is the atomic percentage of the $i$-th element; $r_{i}$ and $r$ are the radius of the atom and the average atomic radius. 
There is also growing interest in composite materials based on HEA alloys with added p-elements such as C, $\mathrm{O}$ or $\mathrm{N}$. This leads to the formation of high-entropy carbides (HEC) [28-30], high-entropy oxides (HEOs) [31, 32] and high-entropy nitrides (HENs) [33]. For the latter class (HENs), a large number of interesting properties have been identified, such as high hardness $[34,35]$, thermal stability and radiation resistance [36], high wear resistance [37], and corrosion resistance $[38,39]$.

Unlike HEA, most HENs publications are related to coating materials. This is due to the simplicity of the synthesis of nitrides in the form of coatings deposited in a nitrogen atmosphere. Among the methods of obtaining the most frequently used method is high-frequency magnetron sputtering in a mixed medium of $\mathrm{Ar}$ and $\mathrm{N}_{2}$, with such a parameter as $R_{\mathrm{N}}=\mathrm{N}_{2} /\left(\mathrm{Ar}+\mathrm{N}_{2}\right)$ [40]. It has been shown that metals that form stable binary nitrides tend to form HENs [41].

At the same time, an important factor that significantly affects the efficiency of nitride formation is the energy of the particles during the formation of nitrides. However, during magnetron sputtering, the degree of ionization is not large. This leads to a low efficiency of influence on the energy characteristics of atoms of such an important parameter as the bias potential of $U_{\mathrm{b}}$. The use of the vacuum-arc method makes it possible to achieve a high degree of ionization and thereby effectively use $U_{\mathrm{b}}$ to change the energy of the particles.

Therefore, the aim was to compare the effect of $U_{\mathrm{b}}$ for vacuum-arc coatings obtained on the basis of different systems of HEA:

- from elements with relatively low affinity for nitrogen $(\mathrm{FeCoNiCuAlCrV})$;

- when partial replacement of elements with low enthalpy of nitrides formation $\Delta \mathrm{H}_{298}^{0}$ on elements with a greater enthalpy of formation of nitrides AlCrTiZrNbV (with replacement $\mathrm{Fe}, \mathrm{Co}, \mathrm{Ni}, \mathrm{Cu}$ on $\mathrm{Ti}, \mathrm{Zr}, \mathrm{Nb}$ ), and AlCrTiNbSi system (by introducing $\mathrm{Si}$ with higher affinity to the nitrogen);

- consisting of elements with a high affinity for nitrogen (TiZrHfVNb).

\section{SAMPLES AND RESEARCH METHODS}

The coatings were deposited by the vacuum-arc method on the modernized installation "Bulat-6".

Previously manufactured a cathode of the required composition by vacuum-arc remelting of a multicomponent mixture of powders of pure metals. Metals with a purity of at least $99.9 \%$ were used as the starting components.

After ten times remelting, the HEA crystallized at a rate of $20 \mathrm{~K} / \mathrm{s}$.

Several types of ingots-billets were prepared based on: AlCrVFeCoNiCu, AlCrTiNbSi, AlCrTiZrNbV, and TiZrNbVHf. From these ingots-billets in the future after mechanical processing cathodes were made (typical view shown in Fig. 1).

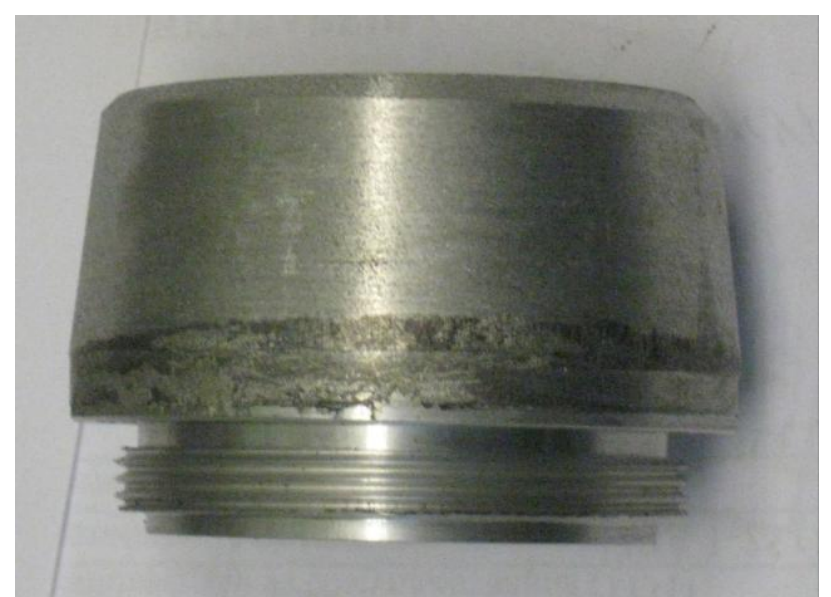

Fig. 1. General view of the cathode before evaporation

Samples of the size $(15 \times 15 \times 2.5 \mathrm{~mm})$ of $12 \times 18 \mathrm{H} 9 \mathrm{~T}$ steel $\left(R_{\mathrm{a}}=0.09 \mu \mathrm{m}\right)$ were chosen as substrates for the deposition of coatings. In the process of deposition, a constant negative bias potential $U_{\mathrm{b}}=-40,-110$, and $-200 \mathrm{~V}$ was is supplied to the substrate. The coatings were deposited at a pressure $P_{\mathrm{N}}=5 \cdot 10^{-3}$ Torr. The deposition time was about 1 hour, which made it possible to obtain coatings with a thickness of $7 \ldots 8 \mu \mathrm{m}$.

The study of the morphology of the cross section of multi-element coatings was carried out on a JEOL JSM840 scanning electron microscope. The elemental composition of the coatings was studied by analyzing the spectra of the characteristic X-ray radiation generated by the electron beam in a scanning electron microscope.

The phase-structural state was studied on a DRON-4 diffractometer in $\mathrm{Cu}-\mathrm{K}_{\alpha}$ radiation. For monochromatization a graphite monochromator was used, which was installed in the secondary beam (in front of the detector) [42]. Measurement was carried out in the angular range of $2 \theta=20 \ldots 80^{\circ}$. All diffraction peaks from the planes with the highest reticular density of atoms fall into this angular range. Scan step $\theta=0.02^{\circ}$. Microindentation was carried out on the installation "Micron-gamma" [43] with a load up to $F=0.5 \mathrm{~N}$ using a Berkovich diamond pyramid with a sharpening angle of $65^{\circ}$, with automatically performed loading and unloading for $30 \mathrm{~s}$.

\section{RESEARCH RESULTS}

In multi-element coatings, the composition may vary significantly with varying process parameters. In this work, $U_{\mathrm{b}}$ used as a technological parameter affecting on the composition.

First, we consider the effect of $U_{\mathrm{b}}$ on the composition of coatings, which consist of elements with the lowest enthalpy of formation of nitrides (based on $\mathrm{AlCrVFeCoNiCu}$ ).

In the initial state, the cathode for evaporation had the elemental composition: $\mathrm{Fe}-15, \mathrm{Co}-15, \mathrm{Ni}-13$, $\mathrm{Cu}-20, \mathrm{Al}-8, \mathrm{Cr}-19, \mathrm{~V}-10$ at.\%. The elemental composition of the deposited coatings are shown in Tabl. 1. 
Table 1

The elemental composition (FeCoNiCuAlCrV)N coatings (at.\%) taking into account the nitrogen content

\begin{tabular}{|c|c|c|c|c|c|c|}
\hline$U_{\mathrm{b}}, \mathrm{V}$ & $\mathrm{Ti}$ & $\mathrm{Cr}$ & $\mathrm{Al}$ & $\mathrm{Nb}$ & $\mathrm{Si}$ & $\mathrm{N}$ \\
\hline-40 & 21.0 & 12.9 & 10.6 & 7.5 & 2.7 & 45.3 \\
\hline-110 & 23.1 & 13.5 & 10.3 & 7.2 & 1.9 & 44.0 \\
\hline-200 & 30.1 & 13.4 & 9.8 & 7.5 & 1.3 & 37.9 \\
\hline
\end{tabular}

From Tabl. 1 it can be seen that the supply of $U_{\mathrm{b}}$ leads to a selective change in composition. To the greatest extent the content of $\mathrm{Cu}$ decreases. Also significantly decreases the content of $\mathrm{N}$. The relative content of the remaining elements slightly increases.
In coatings obtained on the basis of the AlCrTiZrNbV alloy (in which, instead of $\mathrm{Cu}, \mathrm{Fe}, \mathrm{Co}$, $\mathrm{Ni}$, introduce elements $\mathrm{Ti}, \mathrm{Zr}, \mathrm{Nb}$ with strongly bond with nitrogen), a change in $U_{\mathrm{b}}$ also leads to a change in the elemental composition. The results of the elemental analysis are given in Tabl. 2 .

It can be seen that with this combination of $d$ elements in a HEA, the critical element by which occurs of depleted the alloy is Al. The observed relative decrease in the aluminum content is apparently determined by its selective spraying of heavy atoms from the growth surface. As $U_{\mathrm{b}}$ increases, the $\mathrm{N}$ content in the coating also decreases. However, this decrease is less significant compared to ( $\mathrm{FeCoNiCuAlCrV}) \mathrm{N}$ coatings.

Elemental composition (AlCrTiZrNbV)N coatings obtained at different bias potential

Table 2

\begin{tabular}{|c|c|c|c|c|c|c|c|c|}
\hline$U_{\mathrm{b}}, \mathrm{V}$ & $\mathrm{Fe}$ & $\mathrm{Co}$ & $\mathrm{Ni}$ & $\mathrm{Cu}$ & $\mathrm{Al}$ & $\mathrm{Cr}$ & $\mathrm{V}$ & $\mathrm{N}$ \\
\hline-40 & 10.8 & 10.3 & 8.8 & 12.8 & 5.8 & 13.4 & 7.2 & 30.8 \\
\hline-110 & 12.3 & 12.3 & 10.6 & 7.6 & 5.5 & 13.9 & 8.6 & 29.0 \\
\hline-200 & 14.0 & 13.0 & 12.6 & 6.8 & 6.3 & 15.8 & 9.0 & 21.5 \\
\hline
\end{tabular}

Tabl. 3 shows the resulting data on the influence of $U_{\mathrm{b}}$ on the composition of coatings based on the AlCrTiNbSi high-entropy alloy. As the main difference of the elemental composition from the previous series can be considered the addition of a strong nitrideforming element - Si. However, with increasing $U_{\mathrm{b}}$, occurs a decrease in the content of $\mathrm{Si}$. This gives reason to believe that the main reason for this effect is the sputtering of light atoms (as the predominant factor in the formation of the composition of coatings in the deposition process) in comparison with nitride-forming.

Table 3

The elemental composition (AlCrTiNbSi)N coatings of 3 series obtained at different bias potential

\begin{tabular}{|c|c|c|c|c|c|c|c|}
\hline $\begin{array}{c}U_{\mathrm{b}}, \\
\mathrm{V}\end{array}$ & $\mathrm{Ti}$ & $\mathrm{Zr}$ & $\mathrm{Al}$ & $\mathrm{V}$ & $\mathrm{Nb}$ & $\mathrm{Cr}$ & $\mathrm{N}$ \\
\hline-40 & 11.8 & 10.0 & 6.4 & 9.1 & 12.1 & 10.3 & 40.3 \\
\hline-110 & 12.4 & 11.6 & 4.3 & 9.2 & 14.7 & 11.7 & 36.1 \\
\hline-200 & 11.3 & 15.4 & 2.8 & 11.0 & 18.7 & 16.3 & 24.6 \\
\hline
\end{tabular}

To the greatest extent of all strong nitride-forming elements have been used in coatings on based TiZrNbVHf. Tabl. 4 shows the results of elemental analysis for different deposition conditions. It can be seen that in this case (when a large specific content of heavy metal atoms in the alloy) during coating deposition, occurs the relative content of atoms $\mathrm{V}$ decreases (i. e. the element with the lowest relative heat of formation of nitrides). At the same time, the nitrogen content in coatings for the whole range of values $U_{\mathrm{b}}=-40 \ldots-200 \mathrm{~V}$ remains relatively large (close to stoichiometric for mononitride).
Elemental composition (at.\%) of coatings based

Table 4 on HEA TiZrNbVHf

\begin{tabular}{|c|c|c|c|c|c|c|}
\hline$U_{\mathrm{b}}, \mathrm{V}$ & $\mathrm{Ti}$ & $\mathrm{Zr}$ & $\mathrm{Hf}$ & $\mathrm{Nb}$ & $\mathrm{V}$ & $\mathrm{N}$ \\
\hline-50 & 19.8 & 8.3 & 10.1 & 6.4 & 5.1 & 50.3 \\
\hline-100 & 21.2 & 7.9 & 9.8 & 6.1 & 4.9 & 49.8 \\
\hline-200 & 18.2 & 11.9 & 10.5 & 6.9 & 3.2 & 48.3 \\
\hline
\end{tabular}

Thus, in the case of a large difference in the masses of the metal atoms that make up the HEA, with an increase in the particle energy (with an increase in $U_{\mathrm{b}}$ ), occurs a predominant sputtering of light metal atoms. For compositions of heavy metal atoms, occurs predominant depletion of coatings with atoms having the lowest bond energy with nitrogen.

To establish the laws of the influence of $U_{\mathrm{b}}$ on the morphology of growth of coatings, studies of the cross section during the fracture of the "coating on copper foil" system were conducted.

It is known that the main drawback of nitride coatings obtained by the vacuum-arc method is the formation of atoms not reacting with nitrogen in the form of a droplet phase. As can be seen from Fig. 2, with an increase in $U_{\mathrm{b}}$ in HEA, occurs decrease both the average number and the size of droplet formations.

To research the phase composition and structural state of the coatings, an X-ray diffraction analysis method was used. Common to all types of coatings is the formation of a single-phase state solid solution based on the FCC metal lattice (structural type $\mathrm{NaCl}$ ).

Fig. 3 shows the XRD patterns of (AlCrVFeCo$\mathrm{NiCu}) \mathrm{N}$ coatings obtained at pressure $P_{\mathrm{N}}=5 \cdot 10^{-3}$ Torr and $U_{\mathrm{b}}=-40 \mathrm{~V}$ (see Fig. 3, spectrum 1) and $U_{\mathrm{b}}=-200 \mathrm{~V}$ (see Fig. 3, spectrum 2). 

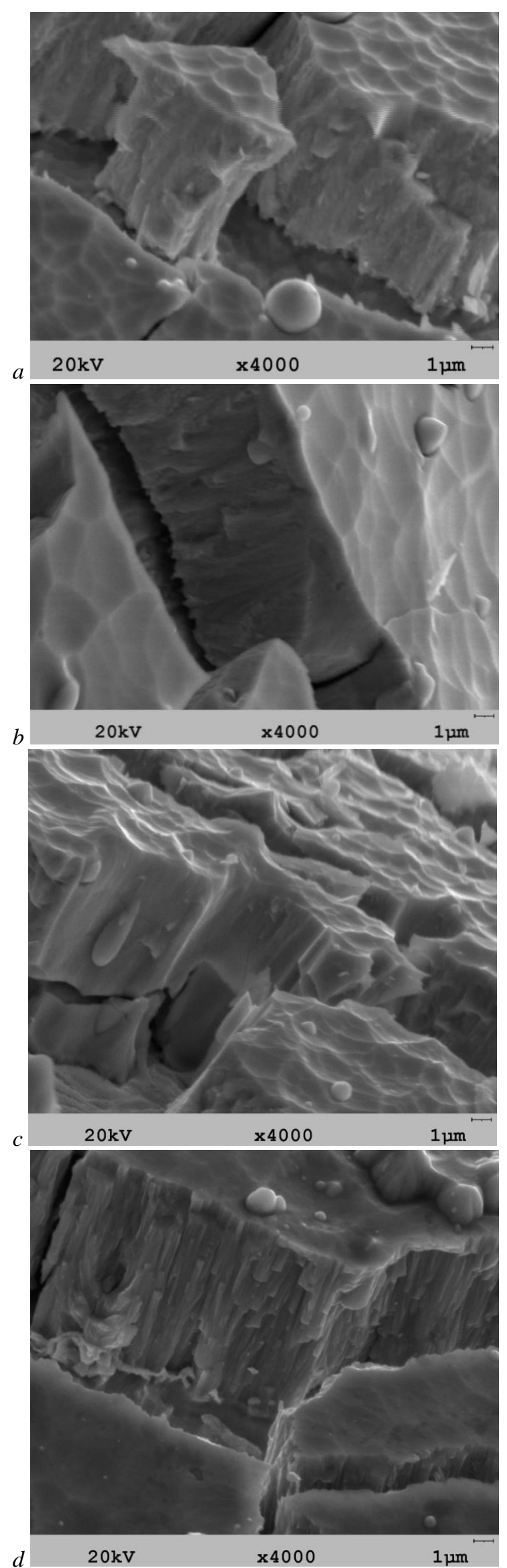

Fig. 2. Morphology of the side surface (TiZrHfVNb)N coatings deposited at $U_{b}=-40(a)$ and $-200 \mathrm{~V}(b)$ and

(TiZrAlVNbCr) N coatings deposited at $U_{b}=-110(c)$ and $-200 \mathrm{~V}(d)$
An analysis of the diffraction spectra shows that at the smallest $U_{\mathrm{b}}=-40 \mathrm{~V}$ a polycrystalline structure is formed with a preferential orientation of a part of crystallites with the [111] axis perpendicular to the growth surface (texture of the axial type with low perfection). With an increase in $U_{\mathrm{b}}$ to $-200 \mathrm{~V}$, a change in the type of texture is observed. In this case, the axis of the predominant growth of crystallites becomes [110] (see Fig. 3, spectrum 2).

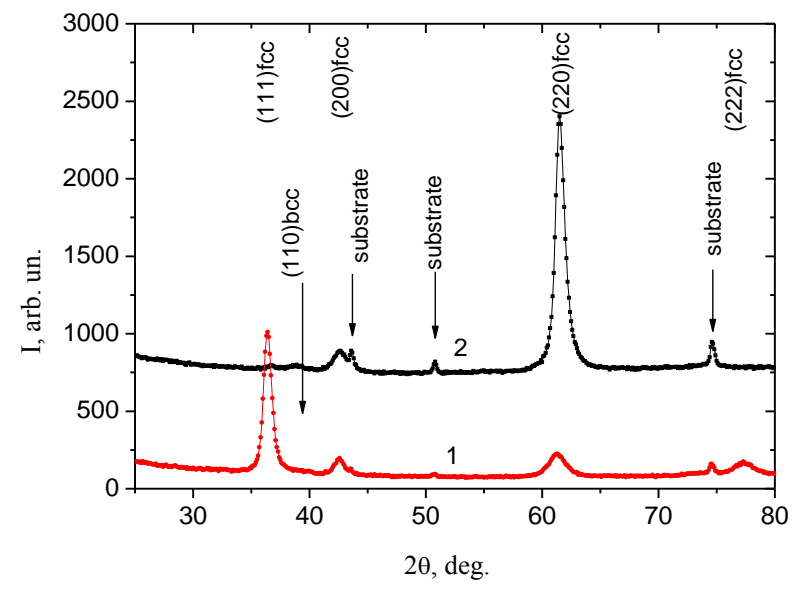

Fig. 3. XRD patterns of the (AlCrVFeCoNiCu)N coatings obtained at $P_{N}=5 \cdot 10^{-3}$ Torr:

$$
U_{b}=-40(1),-200 \mathrm{~V}(2)
$$

Important structural characteristics of the coatings are the average crystallite size. In coatings of this series, the average crystallite size is about $11 \mathrm{~nm}$.

XRD patterns of (AlCrTiZrNbV)N high-entropy alloy coatings are shown in Fig. 4. It is seen that in this case, the change in $U_{\mathrm{b}}$ to a lesser extent affects the change in the preferential orientation of growth. At $U_{\mathrm{b}}=-40 \mathrm{~V}$, the coatings are practically non-textured (see Fig. 4, spectrum 1). At $U_{\mathrm{b}}=-110 \mathrm{~V}$, texture formation with the [100] axis is visible (see Fig. 4, spectrum 2). However, with a larger $U_{\mathrm{b}}$, this type of texture does not appear. With an increase in $U_{\mathrm{b}}$ to $-200 \mathrm{~V}$, texture formation with (a low perfection) [110] axis is seen (see Fig. 4, spectrum 3).

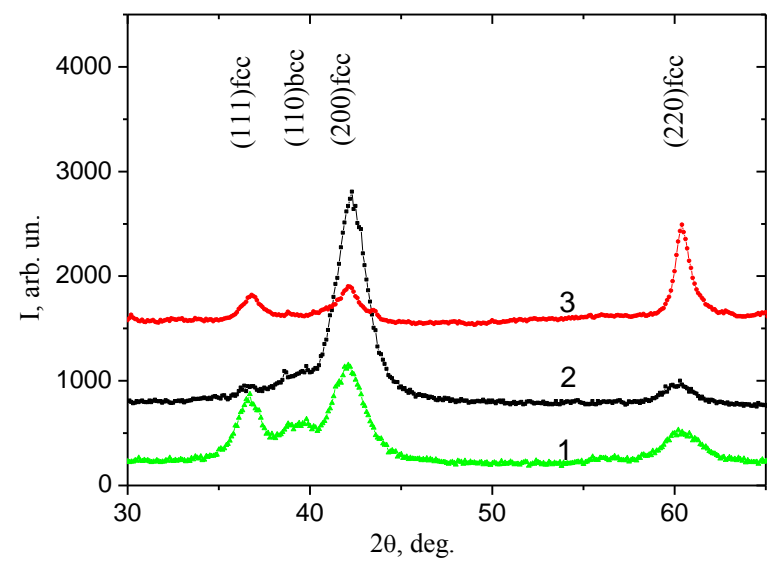

Fig. 4. XRD patterns of the (AlCrTiZrNbV)N coatings obtained at $P_{N}=5 \cdot 10^{-3}$ Torr: $U_{b}=-40(1) ;-110(2) ;-200 \mathrm{~V}(3)$

The average crystallite size for coatings obtained at $U_{\mathrm{b}}=-40 \ldots-110 \mathrm{~V}$ was about $5 \mathrm{~nm}$, which is significantly less than the typical crystallite size for (AlCrVFeCo$\mathrm{NiCu}) \mathrm{N}$ coatings. In coatings obtained at $U_{\mathrm{b}}=-200 \mathrm{~V}$, 
the average crystallite size increased strongly and was about $10.5 \mathrm{~nm}$. The latter effect, apparently, is a consequence of the action of defects annealing in the process of ion bombardment and the relaxation processes associated with it.

It should be noted that for similar types of coatings, but produced under conditions of low plasma ionization (magnetron sputtering), results were obtained in [44]. In this case, it was shown that as $U_{\mathrm{b}}$ changes from 0 to $-150 \mathrm{~V}$, the structural state of the coatings changes from texture with the [100] axis to texture with the [111] axis. At the same time, the compressive macrostresses increase from -0.9 to $-6.6 \mathrm{GPa}$. Also, at highest $U_{\mathrm{b}}$, the highest hardness was $36.9 \mathrm{GPa}$ and the adhesive strength was $60.7 \mathrm{~N}$.

For multi-element nitride (AlCrTiNbSi)N diffraction spectra are shown in Fig. 5. As can be seen from the diffraction spectra, the main phase is a nitride of a solid solution with an FCC type crystal lattice. As the bias potential increases from -40 to $-200 \mathrm{~V}$ (spectra 1 and 3 , respectively), the preferential orientation of growing crystallites changes from the [111] texture axis to [100], which is typical when the material is depleted on the interstitial element (N) [12].

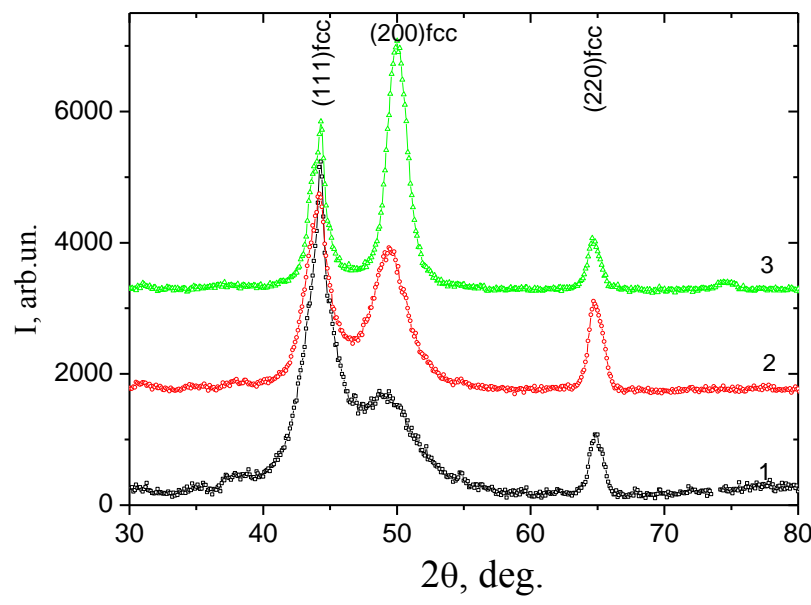

Fig. 5. XRD patterns of the (AlCrTiNbSi)N coatings: $U_{b}=-40(1),-110(2),-200 \mathrm{~V}(3)$

The lattice period decreases from 0.371 to $0.363 \mathrm{~nm}$ with an increase in the bias potential. The crystallite size in the direction perpendicular to the surface plane increases from 3.5 to $8.1 \mathrm{~nm}$ with an $U_{\mathrm{b}}$ increase.

XRD patterns of the (TiZrHfVNb)N coatings are shown in Fig. 5. It can be seen that the [111] texture of low perfection is formed at the lowest potential of $-50 \mathrm{~V}$ (Fig. 6, spectrum 1).

At a higher negative bias potential of $-100 \mathrm{~V}$, the tendency to form coatings with the [111] texture remains (see Fig. 6, spectrum 2). In this case, the degree of perfection of the texture (compared with $U_{\mathrm{b}}=-50 \mathrm{~V}$ ) is much higher, which is manifested in the almost complete absence of diffraction peaks in the spectrum from other planes.

The highest degree of texturing corresponds to the coatings obtained at the highest $U_{\mathrm{b}}=-200 \mathrm{~V}$ (see Fig. 6, spectrum 3).

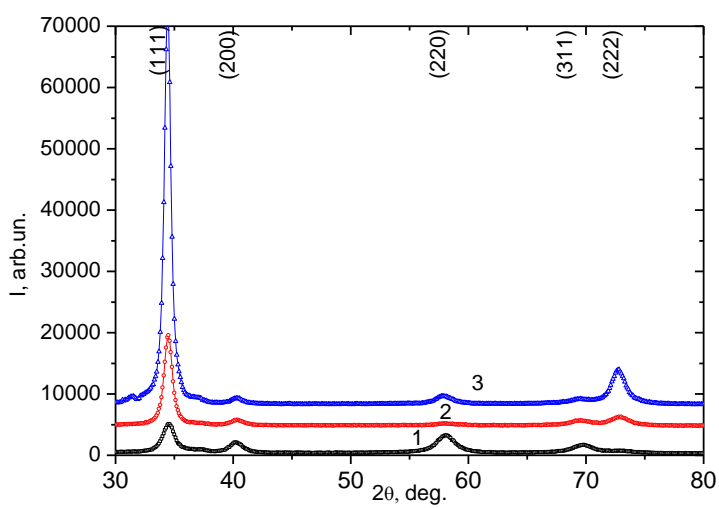

Fig. 6. XRD patterns of the (TiZrHfVNb)N coatings: $U_{b}=-50(1),-100(2),-200 \mathrm{~V}(3)$

The crystallite size with increasing $U_{\mathrm{b}}$ varied from $8.5 \mathrm{~nm}(-50 \mathrm{~V})$ to $11.7 \mathrm{~nm}(-200 \mathrm{~V})$.

The final stage of structural engineering is the establishment of patterns of influence of structural states on functional (physico-mechanical) properties. The most expressive and versatile is the study of physicomechanical properties by measuring hardness.

Fig. 7 shows the comparative dependences of $H\left(U_{\mathrm{b}}\right)$ for all the coatings studied in the work. It can be seen that the obtained dependences $H\left(U_{\mathrm{b}}\right)$ can be divided into 3 characteristic types of curves.

The first type can be attributed to the form of a curve for nitride HEA coatings from elements having a relatively low nitride-forming ability ( $\mathrm{FeCoNiCuAlCrV}$ ). For this type of $\mathrm{H}\left(U_{\mathrm{b}}\right)$ dependence, the highest hardness is achieved at the lowest $U_{\mathrm{b}}$ (see Fig. 7, dependence 1). With an increase in $U_{\mathrm{b}}$, occurs a sharp decrease in the hardness of coatings of this type.

The second type includes coatings in which metal elements are present with both high and relatively low heat of formation of nitrides. This type of $H\left(U_{\mathrm{b}}\right)$ dependence is characteristic of the systems (AlCrTiZrNbV)N (see Fig. 7, dependence 2) and (AlCrTiNbSi)N (see Fig. 7, dependence 3). In this case, the highest hardness is achieved with average values of $U_{\mathrm{b}}$.

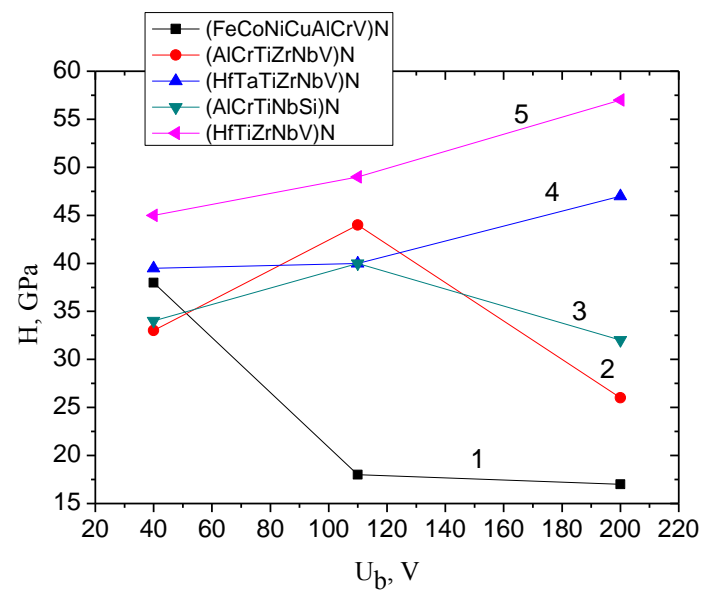

Fig. 7. Dependence of hardness $(H)$ of the magnitude of the bias potential $\left(U_{b}\right)$ for vacuum-arc coatings based on nitrides of $H E A$ :

$1-(\mathrm{FeCoNiCuAlCrV}) \mathrm{N} ; 2-(\mathrm{AlCrTiZrNbV}) \mathrm{N}$; $3-(\operatorname{AlCrTiNbSi}) N ; 4-(H f T a T i Z r N b V) N$; $5-(H f T i Z r N b V) N$ 
The type of curve for a HENs coatings consisting of elements with the highest nitride-forming ability can be attributed to the third type. This type includes (HfTiZrNbV)N coatings (see Fig. 7, dependence 5), as well as described previously in [45] the high-entropy coatings (HfTaTiZrNbV)N (see Fig. 7, dependence 4). It is seen that this type of coating is characterized by a continuous increase in hardness with increasing $U_{\mathrm{b}}$ in the range of $40 \ldots 200 \mathrm{~V}$. In absolute values, the hardness for this type of coating is greatest.

\section{DISCUSSION OF THE RESULTS}

During the formation of coatings in a nitrogen atmosphere, the most important thermodynamic characteristic is the enthalpy of formation of nitride $\Delta \mathrm{H}_{298}^{0}$. For multi-element coatings, this thermodynamic parameter is determined by the contribution of each of the elements. Values $\Delta \mathrm{H}_{298}^{0}$ for nitrides of elements used in this work are given in Tabl. 5.

Table 5

The enthalpy of formation of nitrides for the elements included in the basis of high-entropy alloys

\begin{tabular}{|c|c|c|c|c|c|c|c|}
\hline Nitride & $\mathrm{Si}_{3} \mathrm{~N}_{4}$ & $\mathrm{HfN}$ & $\mathrm{ZrN}$ & $\mathrm{AlN}$ & $\mathrm{TiN}$ & $\mathrm{VN}$ & $\mathrm{TaN}$ \\
\hline$\Delta \mathrm{H}_{298}^{0}, \mathrm{~kJ} / \mathrm{mol}$ & 748 & 369.44 & 365.51 & 320.29 & 336.62 & 251.21 & 247.02 \\
\hline Nitride & $\mathrm{NbN}$ & $\mathrm{CrN}$ & $\mathrm{MoN}$ & $\mathrm{FeN}$ & $\mathrm{NiN}$ & $\mathrm{CoN}$ & $\mathrm{Cu}_{3} \mathrm{~N}$ \\
\hline$\Delta \mathrm{H}_{298}^{0}, \mathrm{~kJ} / \mathrm{mol}$ & 237.81 & 118.07 & 69.50 & 3.77 & -0.84 & -8.37 & -74.53 \\
\hline
\end{tabular}

Based on the data in Tabl. 5, the elemental composition of HEA with the highest properties may have lower functional characteristics during the formation of nitrides. An example of this is the AlCrVFeCoNiCu alloy studied in this work.

When analyzing the elemental composition, it should be noted that for coatings based on AlCrVFe$\mathrm{CoNiCu}$ (containing d-elements with the lowest heat of formation of nitrides) with increasing bias potential in the coating, the content of $\mathrm{Fe}, \mathrm{Co}, \mathrm{Ni}, \mathrm{V}$ atoms is increased. Content of the $\mathrm{Cu}$ (to the greatest extent), $\mathrm{Cr}$, and $\mathrm{Al}$ decreases. Thus, during the deposition of coatings in a nitrogen atmosphere, the relative content of nitride-forming elements increases. At the same time, the relative content of copper atoms (having a low bond energy with nitrogen) is greatly reduced. Thus, the most significant factor in the formation of the elemental composition is the bond strength between the metallic atoms and the nitrogen atoms (in the formation of nitride). This fact indicates that elements with different masses, but high binding energy with nitrogen are retained in the coating. At the same time, elements with a high mass but low enthalpy of formation of nitrides are removed from the coating. This can only happen when spraying near the growth surface, when the bound metal-nitrogen complexes have a low sputtering coefficient.

The change in elemental composition for HENs based on AlCrTiNbSi and AlCrTiZrNbV showed that the use in the first alloy of a strong nitride-forming, but light element ( $\mathrm{Si}$ ) is not an obstacle to reducing its content in the coating with increasing $U_{\mathrm{b}}$ (see Tabl. 3). There is also a depletion of the lightest element (Al) during the deposition of nitride coatings based on the HEA AlCrTiZrNbV (see Tabl. 2).

In coatings based on the heaviest elements (HfTiZrNbV) with an increase in $U_{\mathrm{b}}$, depletion of the lightest elements ( $\mathrm{Ti}$ and $\mathrm{V}$ ) occurs. However, to the greatest extent depletion is $\mathrm{V}$ occurs which has a relatively low nitride formation enthalpy compared to Ti. Thus, in this case, 2 critical mechanisms of depletion are manifested: the smallest mass and relatively low $\Delta \mathrm{H}_{298}^{0}$.

There is also a characteristic decrease in the relative content of nitrogen atoms in the coating with a decrease in the specific component of the elements with a relatively large $\Delta \mathrm{H}_{298}^{0}$ formation of nitride.

The composition of coatings affects the change in the structural state. For coatings consisting of elements with a relatively small (first series based on AlCrVFe$\mathrm{CoNiCu}$ ), when applying $U_{\mathrm{b}}=-200 \mathrm{~V}$, occurs formed a texture with the [110] axis (see Fig. 3, spectrum 2). The formation of such a texture is stimulated by ion bombardment processes and is facilitated by the low content of nitrogen atoms in the coating (providing covalent polar bonds). For coatings based on the HEA AlCrTiZrNbV, similar effect is less pronounced (see Fig. 4). Apparently this determines greater hardness of (AlCrTiZrNbV)N coatings compared with hardness of (AlCrVFeCoNiCu)N coatings at $U_{\mathrm{b}}=-200 \mathrm{~V}$.

The use of $\mathrm{Si}$ as a component leads to a strong dispersion of crystallites (up to $3.5 \mathrm{~nm}$ ) with a silicon content of $1.9 \ldots 2.7$ at.\%. When the silicon content decreases to 1.3 at.\%, occurs the average crystallite size increases and the hardness of the coatings decreases.

For coatings consisting of elements with relatively large $\Delta \mathrm{H}_{298}^{0}$ (with a nitrogen composition close to stoichiometric), a texture with an [111] axis perpendicular to the growth surface is formed in the entire range of $U_{b}$ used (see Fig. 6). In this case, the arrangement of the (111) planes with the highest reticular density parallel to the growth surface provides the minimum energy of the deformation factor $\left(E_{\mathrm{s}} \sim E \varepsilon^{2}\right)$. The kinetic factor is also minimized due to the highest growth rate in the [111] direction (by alternating layers of metal and nitrogen atoms with form a multilayer system with an angstromy period in the direction of the [111] axis).

When analyzing the results on the hardness of coatings, it should be noted that despite the fact that the coatings obtained on the basis of an alloy of seven elements (FeCoNiCuAlCrV systems) represent a singlephase state, the hardness of such a coating does not exceed $38 \mathrm{GPa}$ (see Fig. 7). Thus, an analysis of the mechanical properties of coatings from the multicomponent $\mathrm{FeCoNiCuAlCrV}$ alloy (in which the number of nitride-forming elements with a strong bond is less than that with a weak bond) showed that such compositions can have high functional properties only at low energy 
of bombarding particles (which is accompanied by sputtering of the of the coating during its formation) during deposition. In this paper, this is manifested at the lowest $U_{\mathrm{b}}=-40 \mathrm{~V}$.

From the comparative data in Fig. 7 it can be seen that for coatings based on (FeCoNiCuAlCrV), the highest hardness was obtained at $U_{\mathrm{b}}=-40 \mathrm{~V}$. In this case, a polycrystalline practically non-textured structure is formed, which is characterized by obstruction of sliding along the planes of the crystallites (in this case, the material properties become close to the elastic limit). In this case, the level of the maximum achievable hardness is approximately the same for all types of coatings.

At a higher bias potential $\left(U_{\mathrm{b}}=-110 \mathrm{~V}\right)$, occurs a relative increase in the hardness of coatings consisting of a stronger nitride-forming elements. And with the largest $U_{\mathrm{b}}=-200 \mathrm{~V}$, the highest hardness is achieved in (HfTiZrNbV)N coatings consisting of the strongest nitride-forming elements.

Thus, only in multi-element coatings consisting of elements with a high nitride-forming ability (greater gain in free energy during the formation of nitride), an increase in the energy of the particles (due to an increase in $U_{\mathrm{b}}$ ) can significantly increase the hardness.

\section{CONCLUSIONS}

1. For all types of HEA studied in the work, the deposition in nitrogen atmosphere leads to the formation of a single-phase state (fcc metal lattice, structural type $\mathrm{NaCl})$.

2. It has been established that the selective change in composition during deposition is due to two main processes: if an element with a very low enthalpy of formation of nitride $(\mathrm{Cu})$ is present in an alloy, the coating is depleted of this element, but at a sufficiently high enthalpy of all forming elements, the relative content of the lightest component decreases.

3. An increase in $U_{\mathrm{b}}$ leads to a decrease in the relative content of nitrogen atoms in the coating. This is most pronounced in $\mathrm{HENs}$ based on ( $\mathrm{FeCoNiCuAlCrV})$. Those coatings with a high specific content of elements having a low affinity with nitrogen.

4. When the content of nitrogen atoms is close to stoichiometric (for mononitride), the axis of the preferential orientation of the [111] crystallites is formed. In the (FeCoNiCuAlCrV)N and (AlCrTiZrNbV)N coatings at $U_{\mathrm{b}}=-200 \mathrm{~V}$ and a large deficiency in nitrogen atoms, a texture with the [110] axis forms. The formation of the [110] texture is determined by the minimal influences of the factor of ion bombardment during the growth of the coating.

5. When classifying the $H\left(U_{\mathrm{b}}\right)$ dependencies, 3 characteristic types were revealed. The first type - with the highest $H$ value at low $U_{\mathrm{b}}$. This type is characteristic of $(\mathrm{FeCoNiCuAlCrV}) \mathrm{N}$ coatings in which a significant portion of the metal atoms has a small affinity with the nitrogen atoms. The second type of dependence $H\left(U_{\mathrm{b}}\right)$ has a curve with a maximum hardness at $U_{\mathrm{b}} \approx-110 \mathrm{~V}$. This type is characteristic of $(\mathrm{AlCrTiZrNbV}) \mathrm{N}$ and (AlCrTiNbSi)N coatings. For coatings (HfTiZrNbV)N, consisting of strong nitride-forming elements with increasing $U_{\mathrm{b}}$, occurs continuous increase in hardness. This is the third type of dependence $H\left(U_{\mathrm{b}}\right)$ and in this case the greatest hardness is reached, exceeding $45 \mathrm{GPa}$.

\section{REFERENCES}

1. M.V. Kindrachuk, Yu.Ya. Dushek, M.V. Luchka, A.N. Gladchenko. The structure evolution and properties of eutectic coatings in friction // Poroshkovaya Metallurgiya. 1995, N 5-6, p. 104-110 (in Russian).

2. M.O. Vasyliev, B.M. Mordyuk, S.I. Sidorenko, S.M. Voloshko, A.P. Burmak, M.V. Kindrachuk. Synthesis of deformation-induced nanocomposites on aluminium D16 alloy surface by ultrasonic impact treatment. // Metallofizika i Noveishie Tekhnologii. 2016, N 38(4), p. 545-563 (in Russian).

3. O.V. Sobol', A.A. Andreev, V.F. Gorban', A.A. Meylekhov, H.O. Postelnyk, V.A. Stolbovoy. Structural engineering of the vacuum Arc ZrN/CrN multilayer coatings // Journal of Nano- and Electronic Physics. 2016, v. 8, issue 1, p. 01042-1-01042-5.

4. O.V. Sobol', A.A. Postelnyk, A.A. Meylekhov, A.A. Andreev, V.A. Stolbovoy, V.F. Gorban'. Structural engineering of the multilayer vacuum Arc nitride coatings based on $\mathrm{Ti}, \mathrm{Cr}$, Mo, and $\mathrm{Zr} / /$ Journal of Nano- and Electronic Physics. 2017, N 9(3), p. $03003-$ 1-03003-6.

5. M.A. Glushchenko, V.V. Belozyorov, O.V. Sobol', V.V. Subbotina, G.I. Zelenskaya, A.I. Zubkov. Effect of tantalum on the texture of copper vacuum condensates // Journal of Nano- and Electronic Physics. 2017, N 9(2), p. 02015-1-02015-5.

6. V.I. Ivashchenko, S.N. Dub, P.L. Scrynskii, A.D. Pogrebnjak, O.V. Sobol', G.N. Tolmacheva, V.M. Rogoz, A.K. Sinel'chenko. Nb-Al-N thin films: Structural transition from nanocrystalline solid solution $\mathrm{nc}-(\mathrm{Nb}, \mathrm{Al}) \mathrm{N}$ into nanocomposite $\mathrm{nc}-(\mathrm{Nb}, \mathrm{Al}) \mathrm{N} / \mathrm{a}-\mathrm{AlN}$ // Journal of Superhard Materials. 2016, v. 38, issue 2, p. 103-113.

7. O. Sobol'. The influence of nonstoichiometry on elastic characteristics of metastable $\beta-\mathrm{WC}_{1-\mathrm{x}}$ phase in ion plasma condensates // Technical Physics Letters. 2016, N 42, v. 9, p. 909-911.

8. P.H. Mayrhofer, C. Mitterer, L. Hultman, H. Clemens. Microstructural design of hard coatings // Progress in Materials Science. 2006, N 51, p. 10321114.

9. S. Veprek. The search for novel, superhard materials // J. Vac. Sci. Technol. 1999, v. A. 17, p. 24012420 .

10. O.V. Sobol', A.A. Andreev, V.F. Gorban', V.A. Stolbovoy, A.A. Meylekhov, A.A. Postelnyk, A.V. Dolomanov. Influence of pressure of working atmosphere on the formation of phase-structural state and physical and mechanical properties of vacuum-arc multilayer coatings $\mathrm{ZrN} / \mathrm{CrN} / /$ Problems of Atomic Science and Technology. 2016, N 1(101), p. 134-139.

11. Nanostructured coatings / Edited by: Albano Cavaleiro, Jeff Th. M. de Hosson. Springer-Verlag, 2006, 648 p.

12. O.V. Sobol'. Structural engineering vacuumplasma coatings interstitial phases // Journal of Nanoand Electronic Physics. 2016, v. 8, issue 2, p. 02024-102024-7.

13. O.V. Sobol', A.A. Andreev, V.F. Gorban', V.A. Stolbovoy, A.A. Melekhov, A.A. Postelnyk. Pos- 
sibilities of structural engineering in multilayer vacuumarc $\mathrm{ZrN} / \mathrm{CrN}$ coatings by varying the nanolayer thickness and application of a bias potential // Technical Physics. 2016, N 61(7), p. 1060-1063.

14. M.A. Glushchenko, E.V. Lutsenko, O.V. Sobol', A.E. Barmin, A.I. Zubkov. The influence of copper condensates alloying with Co, Mo, Ta transition metals on the structure and the hall-petch dependence // Journal of Nano- and Electronic Physics. 2016, N 8(3), p. 03015-1-03015-4.

15. S. Veprek, S. Mukharjee, P. Karvankova, H.D. Maning, J.L. He, K. Moto, J. Prohazka, A.S. Argon. Limits to the strength of super- and ultrahard and nanocomposite coatings // J. Vac. Sci. Technol. 2003, v. A 21 (3), p. 532-544.

16. O.V. Sobol', O.N. Grigoryev, Yu.A. Kunitsky, S.N. Dub, A.A. Podtelezhnikov, A.N. Stetsenko. Peculiarities of structure state and mechanical characteristics in ion-plasma condensates of quasibinary system borides $\mathrm{W}_{2} \mathrm{~B}_{5}-\mathrm{TiB}_{2} / /$ Science of Sintering. 2006, N 38(1), p. 63-72.

17. J.W. Yeh, S.K. Chen, S.J. Lin, J.Y. Gan, T.S. Chin, T.T. Shun, C.H. Tsau, S.Y. Chang. Nanostructured high-entropy alloys with multiple principal elements: novel alloy design concepts and outcomeso // Adv. Eng. Mater. 2004, N 6, p. 299-303.

18. Y.F. Ye, Q. Wang, J. Lu, C.T. Liu, Y. Yang. High-entropy alloy: challenges and prospects // Mater. Today. 2016, N 19, p. 349-362.

19. Y. Zhang, T.T. Zuo, Z. Tang, M.C. Gao, K.A. Dahmen, P.K. Liaw, Z.P. Lu, Microstructures and properties of high-entropy alloys // Prog. Mater. Sci. 2014, N 61, p. 1-93.

20. D.B. Miracle, O.N. Senkov. A critical review of high entropy alloys and related conceptso //Acta Mater. 2017, N 122, p. 448-511.

21. Y. Zou, J.M. Wheeler, H. Ma, P. Okle, R. Spolenak. Nanocrystalline high-entropy alloys: a new paradigm in high-temperature strength and stability // Nano Lett. 2017, N 17, p. 1569-1574.

22. Z. Li, K.G. Pradeep, Y. Deng, D. Raabe, C.C. Tasan. Metastable high-entropy dual-phase alloys overcome the strength-ductility trade-off // Nature. 2016, N 34, p. 227-230.

23. B. Gludovatz, A. Hohenwarter, D. Catoor, E.H. Chang, E.P. George, and R.O. Ritchie. A fractureresistant high-entropy alloy for cryogenic applications // Science. 2014, N 345(6201), p. 1153-1158.

24. M.A. Hemphill, T. Yuan, G.Y. Wang, J.W. Yeh, C.W. Tsai, A. Chuang, and P.K. Liaw. Fatigue behavior of $\mathrm{Al} 0$. 5CoCrCuFeNi high entropy alloys // Acta Materialia. 2012, N 60(16), p. 5723-5734.

25. K.M. Youssef, A.J. Zaddach, C.N. Niu, D.L. Irving, and C.C. Koch. A novel low-density, highhardness, high-entropy alloy with close-packed singlephase nanocrystalline structures // Materials Research Letters. 2015, N 3(2), p. 95-99.

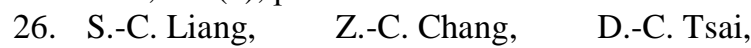
Y.-C. Lin, H.-S. Sung, M.-J. Deng, F.-S. Shieu. Effects of substrate temperature on the structure and mechanical properties of (TiVCrZrHf)N coatings // Appl. Surf. Sci. 2011, N 257, p. 7709-7713.
27. X. Yang, Y. Zhang. Prediction of high-entropy stabilized solid-solution in multi-component alloys // Mater. Chem. Phys. 2012, N 132, p. 233-238.

28. M. Braic, V. Braic, M. Balaceanu, C.N. Zoita, A. Vladescu, E. Grigore. Characteristics of (TiAlCrNbY)C films deposited by reactive magnetron sputtering // Surf. Coat. Technol. 2010, N 204, p. 2010-2014.

29. V. Braic, M. Balaceanu, M. Braic, A. Vladescu, S. Panseri, A. Russo. Characterization of multiprincipal-element (TiZrNbHfTa)N and (TiZrNbHfTa)C coatings for biomedical applications // J. Mech. Behav. Biomed. Mater. 2012, N 10, p. 197-205.

30. P. Malinovskis, S. Fritze, L. Riekehr, L. von Fieandt, J. Cedervall, D. Rehnlund, L. Nyholm, E. Lewin, U. Jansson. Synthesis and characterization of multicomponent (CrNbTaTiW)C films for increased hardness and corrosion resistance // Mater. Design. 2018, N 149, p. 51-62.

31. C.M. Rost, E. Sachet, T. Borman, A. Moballegh, E.C. Dickey, D. Hou, J.L. Jones, S. Curtarolo, J.P. Maria. Entropy-stabilized oxideso //Nat. Commun. 2015, N 6, p. 8485.

32. S. Jiang, T. Hu, J. Gild, N. Zhou, J. Nie, M. Qin, T. Harrington, K. Vecchio, J. Luo. A new class of high-entropy perovskite oxides // Scr. Mater. 2018, N 142, p. 116-120.

33. V.M. Beresnev, O.V. Sobol', U.S. Nyemchenko, S.V. Lytovchenko, G.F. Gorban', V.A. Stolbovoy, D.A. Kolesnikov, A.A. Meylekhov, A.A. Postelnyk, V.Y. Novikov. The influence of nitrogen pressure on the structure of condensates, obtained at vacuum-arc deposition from high entropy alloy AlCrTiZrNbY // Problems of Atomic Science and Technology. 2016, N 2(102), p. 86-91.

34. O.V. Sobol', A.A. Andreev, V.F. Gorban', N.A. Krapivka, V.A. Stolbovoi, I.V. Serdyuk, V.E. Fil'chikov. Reproducibility of the single-phase structural state of the multielement high-entropy Ti-V$\mathrm{Zr}-\mathrm{Nb}-\mathrm{Hf}$ system and related superhard nitrides formed by the vacuum-arc method // Technical Physics Letters. 2012, N 38(7), p. 616-619.

35. C.-H. Lai, S.-J. Lin, J.-W. Yeh, S.-Y. Chang. Preparation and characterization of AlCrTaTiZr multielement nitride coatings // Surf. Coat. Technol. 2006, N 201, p. 3275-3280.

36. A.A. Andreev, V.N. Voyevodin, O.V. Sobol', V.F. Gorban', G.N. Kartmazov, V.A. Stolbovoy, V.V. Levenets, D.V. Lysan. Regularities in the effect of model ion irradiation on the structure and properties of vacuum-arc nitride coatings // Problems of Atomic Science and Technology. 2013, N 5(87), p. 142-146.

37. S.N. Grigoriev, O.V. Sobol', V.M. Beresnev, I.V. Serdyuk, A.D. Pogrebnyak, D.A. Kolesnikov, U.S. Nemchenko. Tribological characteristics of (TiZrHfVNbTa)N coatings applied using the vacuum arc deposition method // Journal of Friction and Wear. 2014, N 35(5), p. 359-364.

38. H.-T. Hsueh, W.-J. Shen, M.-H. Tsai, J.-W. Yeh. Effect of nitrogen content and substrate bias on mechanical and corrosion properties of high-entropy films (AlCrSiTiZr) ${ }_{100-\mathrm{x}} \mathrm{N}_{\mathrm{x}} / /$ Surf. Coat. Technol. 2012, N 206, p. 4106-4112. 
39. D.-C. Tsai, M.-J. Deng, Z.-C. Chang, B.-H. Kuo, E.-C. Chen, S.-Y. Chang, F.-S. Shieu. Oxidation resistance and characterization of (AlCrMoTaTi)-Six-N coating deposited via magnetron sputtering // J. Alloys Compd. 2015, N 647, p. 179-188.

40. Keng-Hao Cheng, Chia-Han Lai, Su-Jien Lin, Jien-Wei Yeh. Structural and mechanical properties of multi-element (AlCrMoTaTiZr)Nx coatings by reactive magnetron sputtering // Thin Solid Films. 2011, N 519, p. 3185-3190.

41. Z.-C. Chang, S.-C. Liang, S. Hano. Effect of microstructure on the nanomechanical properties of TiVCrZrAl nitride films deposited by magnetron sputtering // Nucl. Instrum. Methods Phys. Res. 2011, Sect. B, N 269, p.1973-1976.

42. O.V. Sobol', O.A. Shovkoplyas. On advantages of X-ray schemes with orthogonal diffraction vectors for studying the structural state of ion-plasma coatings // Technical Physics Letters. 2013, N 39(6), p. $536-539$.

43. E. Aznakayev. Proceedings of the International Conference “Small Talk - 2003”, TP.001, 2003, p. 810.

44. C.H. Lai, K.H. Cheng, S.J. Lin, J.W. Yeh. Mechanical and tribological properties of multi-element (AlCrTaTiZr)N coatings // Surf. Coat. Technol. 2008, N 202, p. 3732-3738.

45. I.V. Serdyuk, O.V. Sobol', A.A. Andreev, V.N. Voyevodin, V.F. Gorban', S.N. Grigor'ev, M.A. Volosova. The bias potential and pressure nitrogen effect on structur al stress on the structure-stressed state and properties of nitride coatings produced from high-entropy alloys by the vacuum arc technique // Problems of Atomic Science and Technology. 2014, N 1(89), p. 141-146.

Article received 26.11.2018

\title{
ИСПОЛЬЗОВАНИЕ ОТРИЦАТЕЛЬНОГО ПОТЕНЦИАЛА СМЕЩЕНИЯ ДЛЯ СТРУКТУРНОЙ ИНЖЕНЕРИИ ВАКУУМНО-ДУГОВЫХ НИТРИДНЫХ ПОКРЫТИЙ НА ОСНОВЕ ВЫСОКОЭНТРОПИЙНЫХ СПЛАВОВ
}

\author{
О.В. Соболь, А.А. Андреев, В.Ф. Горбань, А.А. Постельник, В.А. Столбовой, А.В. Звягольский, \\ А.В. Доломанов, Ж.В. Краевская
}

Исследовано влияние отрицательного потенциала смещения ( $U_{\mathrm{b}}=-40,-110$ и -200 В) при осаждении многоэлементных покрытий на их состав, структуру и механические свойства. Установлено, что при переходе от многоэлементного сплава к нитриду на его основе возможно формирование однофазного состояния (на основе ГЦК металлической решетки - структурный тип $\mathrm{NaCl}$ ). При этом состав $(\mathrm{FeCoNiCuAlCrV}) \mathrm{N}$ покрытий с увеличением $U_{\mathrm{b}}$ обедняется элементом с наименьшей энтальпией образования нитрида $(\mathrm{Cu})$. В (AlCrTiNbSi)N- и (AlCrTiZrNbV)N-покрытиях с увеличением $U_{\mathrm{b}}$ уменьшается содержание элементов с малой массой ( $\mathrm{Si}$ и $\mathrm{Al})$. B (TiZrHfVNb)N-покрытиях из сильных нитридообразующих элементов с большой массой при увеличении $U_{\mathrm{b}}$ до 200 В состав практически не изменяется. Структура таких покрытий характеризуется наличием текстуры с осью [111]. Наличие слабых нитридообразующих элементов в (FеСо$\mathrm{NiCuAlCrV)N-покрытиях} \mathrm{приводит} \mathrm{при} \mathrm{больших} U_{\mathrm{b}}=110 \ldots 200 \mathrm{~B}$ к формированию текстуры [110]. В таких покрытиях твердость не превышает 35 ГПа. Показано, что для достижения высокой твердости при больших $U_{\mathrm{b}}$ необходимо увеличивать содержание в высокоэнтропийном сплаве элементов с высокой нитридообразующей способностью. При этом в (TiZrHfVNb)N-покрытиях (из сильных нитридообразующих элементов с большой массой) при $U_{\mathrm{b}}=200 \mathrm{~B}$ твердость превышает 45 ГПа.

\section{ВИКОРИСТАННЯ НЕГАТИВНОГО ПОТЕНЦАЛУ ЗМЩЕННЯ ДЛЯ СТРУКТУРНОӤ ІНЖЕНЕРІЇ ВАКУУМНО-ДУГОВИХ НІТРИДНИХ ПОКРИТТІВ НА ОСНОВІ ВИСОКОЕНТРОПІЙНИХ СПЛАВІВ}

\section{О.В. Соболь, А.О. Андрєєв, В.Ф. Горбань, Г.О. Постельнік, В.О. Столбовий, О.В. Звягольський, А.В. Доломанов, Ж.В. Краєвська}

Досліджено вплив негативного потенціалу зміщення ( $U_{\mathrm{b}}=-40,-110$ i -200 В) при осадженні багатоелементних покриттів на їх склад, структуру і механічні властивості. Встановлено, що при переході від багатоелементного сплаву до нітриду на його основі можливе формування однофазного стану (на основі ГЦК металевої решітки - структурний тип $\mathrm{NaCl}$ ). При цьому склад (FeCoNiCuAlCrV)N-покриттів зі збільшенням $U_{\mathrm{b}}$ збіднюється елементом 3 найменшою ентальпією утворення нітриду (Cu). $\mathrm{y}$ ( $\left.\mathrm{AlCrTiNbSi}\right) \mathrm{N}-\mathrm{i}$ (AlCrTiZrNbV)N-покриттях зі збільшенням $U_{\mathrm{b}}$ зменшується вміст елементів з малою масою ( $\mathrm{Si}$ i $\left.\mathrm{Al}\right)$. У (TiZrHfVNb)N-покриттях, що складаються з сильних нітрідоутворюючих елементів 3 великою масою, при збільшенні $U_{\mathrm{b}}$ до 200 В склад практично не змінюється. Структура таких покриттів характеризується наявністю текстури 3 віссю [111]. Наявність слабких нітрідоутворюючих елементів у $(\mathrm{FeCoNiCuAlCrV}) \mathrm{N}$ покриттях призводить при великих $U_{\mathrm{b}}=110 \ldots 200 \mathrm{~B}$ до формування текстури [110]. У таких покриттях твердість не перевищує 35 ГПа. Показано, що для досягнення високої твердості при великих $U_{\mathrm{b}}$ необхідно збільшувати вміст у високоентропійному сплаві елементів з високою нітрідоутворюючою здатністю. При цьому в (TiZrHfVNb)N-покриттях (з сильних нітрідоутворюючих елементів з великою масою) при $U_{\mathrm{b}}=200 \mathrm{~B}$ твердість перевищує 45 ГПа. 